\title{
Hereditary opalescent dentin
}

\author{
Kaushal Mahendra Shah
}

Departments of Oral Medicine, Diagnosis \& Radiology, Bharati Vidyapeeth Deemed University Dental College, Sangli, Maharashtra, India

\section{Correspondence to}

Dr Kaushal Mahendra Shah, thirty2creations@gmail.com
To cite: Shah KM. BMJ Case Rep Published online: [please include Day Month Year] doi:10.1136/ bcr-2013-008958

\section{DESCRIPTION}

Dentinogenesis imperfecta (DI) is a genetically determined developmental defect of dentine. It is broadly grouped into three categories ${ }^{1}$ : type I: the dental manifestation of osteogenesis imperfect, type II: classical hereditary opalescent dentine and type III: Brandywine isolate opalescent dentine. ${ }^{2}$ The prevalence of DI is 1:8000.

A young patient came to the dental operatory complaining of dull pain in the maxillary right posterior region and poor aesthetics due to discolouration and rapidly wearing tooth surfaces. Patient's medical history was non-contributory. The family history suggested that the patient's maternal grandfather and mother were suffering from the similar condition of rapid wearing of teeth and had undergone total extraction at a young age. Her brother also had similar teeth. Intraoral examination (figure 1) showed generalised amber translucency of teeth, worn out incisal and occlusal surfaces, exposing dentine and decreasing overall vertical dimension of jaws. The Orthopantomograph (figure 2) showed generalised incisal and occlusal wear, bulbous appearing crowns due to constriction of the cervical portion of the roots, tapered and short roots, obliterated pulp and root canal spaces. Other findings included few carious and missing teeth.

A multidisciplinary treatment planning is required for treatment of these individuals, which includes assistance from fellow specialists, such as endodontist, prosthodontist and implantologist.

Total oral rehabilitation of patient is needed with paramount importance to aesthetics, obtaining an appropriate vertical dimension and providing soft tissue support which will help to return the facial profile to a more normal appearance. ${ }^{3}$

In this case, we propose to restore the patient's anterior dentition with laminates to achieve

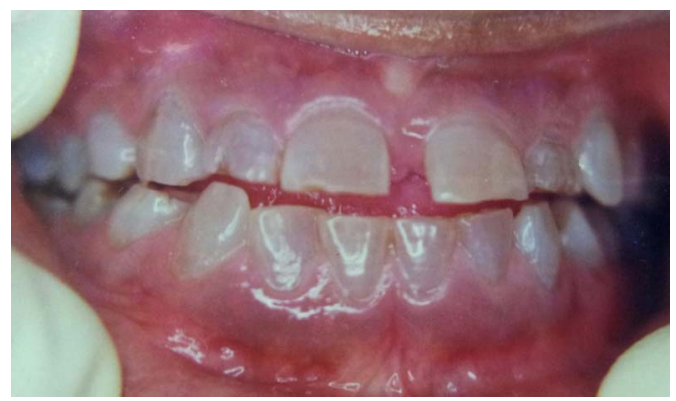

Figure 1 Intraoral photograph. Amber translucent dentition with incisal wear.

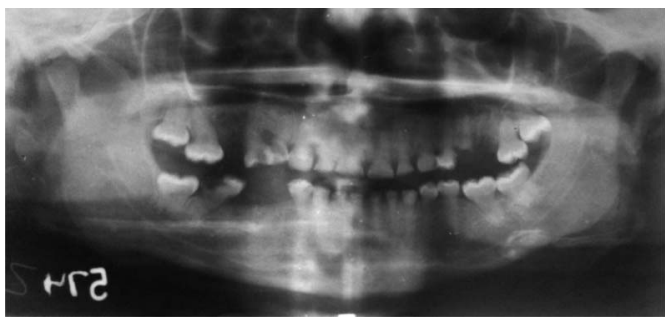

Figure 2 Orthopantomograph. Generalized incisal and occlusal wear, bulbous appearing crowns, tapered and short roots, obliterated pulp and root canal spaces.

optimum aesthetics. Removal of sources of infection and pain, with appropriate restorations and endodontic therapy wherever necessary followed by a combination of full-coverage crowns for posterior teeth to prevent more wearing of teeth and implant supported crowns to replace missing teeth in a reorganised occlusal scheme.

\section{Learning points}

Dentinogenesis imperfecta (DI) is a hereditary developmental disturbance of tooth dentine, and majority may have a positive family history.

- DI will always show generalised greyish, brownish translucent well formed teeth, which over time undergo moderate to severe attrition, as compared to Amelogenesis Imperfecta where the defect lies in enamel, leading to small hypoplastic teeth, or severe pitted surfaces.

\section{Competing interests None.}

Patient consent Obtained.

Provenance and peer review Not commissioned; externally pee reviewed.

\section{REFERENCES}

1 Shields ED, Bixler D, El-Katrawy AM. A proposed classification for heritable human dentine defects with a description of a new entity. Arch Oral Biol 1973;18:543.

2 Witkop CJ Jr, Maclean CJ, Schmidt PJ, et al. Medical and dental findings in the Brandywine isolate. Ala J Med Sci 1966;3:382-403.

3 American Academy of Paediatric Dentistry Council on Clinical Affairs. Guideline on oral health care/dental management of heritable dental development anomalies. Pediatr Dent 20082009;30:196-201. 


\section{Images in...}

Copyright 2013 BMJ Publishing Group. All rights reserved. For permission to reuse any of this content visit http://group.bmj.com/group/rights-licensing/permissions.

BMJ Case Report Fellows may re-use this article for personal use and teaching without any further permission.

Become a Fellow of BMJ Case Reports today and you can:

- Submit as many cases as you like

- Enjoy fast sympathetic peer review and rapid publication of accepted articles

- Access all the published articles

- Re-use any of the published material for personal use and teaching without further permission

For information on Institutional Fellowships contact consortiasales@bmjgroup.com

Visit casereports.bmj.com for more articles like this and to become a Fellow 